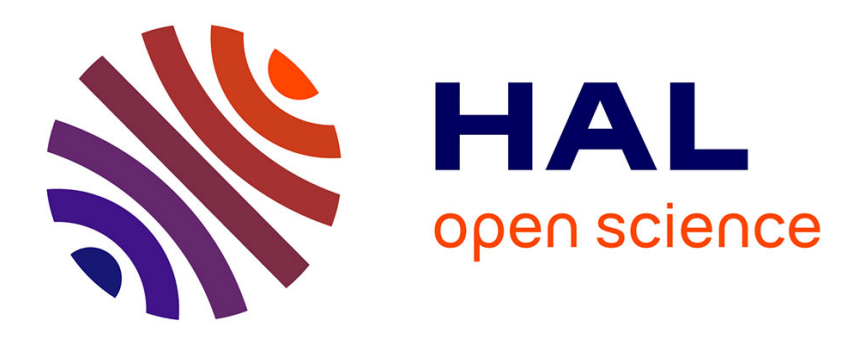

\title{
Judging the Communist Past: Historians and Cultural Expertise in Polish Administrative Courts
}

\author{
Stanislaw Burdziej
}

\section{To cite this version:}

Stanislaw Burdziej. Judging the Communist Past: Historians and Cultural Expertise in Polish Administrative Courts. Law and History Review, 2020, 38, pp.99 - 122. 10.1017/s0738248019000543 . hal-03498736

\section{HAL Id: hal-03498736 \\ https://hal.science/hal-03498736}

Submitted on 21 Dec 2021

HAL is a multi-disciplinary open access archive for the deposit and dissemination of scientific research documents, whether they are published or not. The documents may come from teaching and research institutions in France or abroad, or from public or private research centers.
L'archive ouverte pluridisciplinaire HAL, est destinée au dépôt et à la diffusion de documents scientifiques de niveau recherche, publiés ou non, émanant des établissements d'enseignement et de recherche français ou étrangers, des laboratoires publics ou privés. 


\title{
Judging the Communist Past: Historians and Cultural Expertise in Polish Administrative Courts
}

\author{
STANISŁAW BURDZIEJ
}

\section{Introduction}

Cultural expertise involves "locating and describing relevant facts in light of the particular background of the claimants, litigants, or the accused person(s), and in some cases of the victim(s)." a particular context of Western societies confronting increasing cultural, religious, and ethnic diversity as a result of mass emigration, mainly from their former colonies, and a new appreciation of the rights of Indigenous peoples. In many justice systems, social scientists increasingly assume expert roles to inform court decisions, usually in matters related to immigration and asylum, but also in family law and numerous other subfields of law. ${ }^{2}$ The concept has been developed to study - and bolster - the court's ability to understand minority cultures, in order to enhance the rule of law and human rights, but more recent work has highlighted its relevance

1. Livia Holden, ed., Cultural Expertise and Litigation: Patterns, Conflicts, Narratives (New York: Routledge, 2011), 2.

2. Livia Holden, "Beyond Anthropological Expert Witnessing: Toward an Integrated Definition of Cultural Expertise," in Cultural Expertise and Socio-Legal Studies, ed. Austin Sarat (Bingley, UK: Emerald Publishing Limited, 2019), 181-204.

Stanisław Burdziej is an associate professor of sociology at the Department of Sociology, Nicolaus Copernicus University in Torun, Poland <s.burdziej@umk.pl>. This paper benefitted from academic interactions and financial support from the project entitled "Cultural Expertise in Europe: What is it useful for?" (EURO-EXPERT) funded by the European Research Council (ERC) under H2020-EU Consolidator Grant (ERC grant agreement no. 681814), Principal Investigator: Livia Holden. The author also thanks Daniel Wicenty for his helpful comments. 
for various other disciplines beyond anthropology—especially history and linguistics - and contexts other than immigration. ${ }^{3}$

As Véronique Bouillier has observed in reference to the French experience with cultural expertise, "'culture' is often used in courts as a kind of magic word that serves as the ultimate explanation for any 'strange' behaviour." There is a common perception in Western societies (and, accordingly, in Western court systems) that only minority groups have "culture" that requires explanation. Dominant cultures - and behaviors conforming to standard definitions of ideas such as honor or gender roles - tend to be taken for granted. Therefore, the aim of this article is to further explore the applicability of the concept of cultural expertise to social scientists' special knowledge of their own societies. Cultural (geographic) distance appears to be just one type of distance between lay and expert knowledge and the understanding of "relevant facts." Cultural expertise provided by historians may help courts navigate another distance: namely, time.

Poland is among the countries where recent political transformation has created a demand for transitional justice. ${ }^{5}$ A sequence of historical events over a period of 200 years - the partitioning of the country among Austria, Prussia, and Russia (1772-1918), regained independence and a 20 year long period of state reconstruction (1918-39), German and Soviet occupation (1939-45), Soviet domination (1944-89), and, finally, transition to capitalism and liberal democracy after 1989-involved repeated shifts in meaning and interpretation of historical events, challenging courts to navigate not only different legal orders but also different cultural and symbolic universes. Increased demand for such expertise led to the creation of the Institute of National Remembrance (Instytut Pamięci Narodowej [IPN]) in $1999 .{ }^{6}$ Historical expertise has therefore gained official status in various court proceedings and has been thoroughly institutionalized, with

3. See Livia Holden, "Introduction: Why a History of Cultural Expertise?" Law and History Review 38 (2020): 25-27; and Jerome Bourgon, "Historians at the Court: How Cultural Expertise in Qing Law Contribute to the Invention of Hong Kong Chinese Customary Law" Law and History Review 38 (2020): 85-98.

4. Véronique Bouillier, "French Law Courts and South Asian Litigants," in Cultural Expertise and Litigation: Patterns, Conflicts, Narratives, ed. Livia Holden (New York: Routledge, 2011), 54.

5. For a general discussion of transitional justice in Eastern Europe, see Lavinia Stan, ed., Transitional Justice in Eastern Europe and the Former Soviet Union: Reckoning with the Communist Past (New York: Routledge, 2008).

6. The Institute was established by the Polish Parliament on December 18, 1998, incorporating the earlier Main Commission for the Prosecution of Crimes Against the Polish Nation, and became operational on July 1, 2000. 
implications both for the resolution of relevant court disputes and for historical scholarship in Poland.

Expert witnessing by historians goes beyond the mere establishment of facts, often involving - or directly translating into-judgments of people and events. These judgments bear practical consequences for whole groups of litigants, often numbering tens of thousands of people, such as the loss of the ability to get elected to a public office or the loss of veteran status along with its benefits. Other consequences are less tangible, but perhaps even more poignant, as they involve judgements over interpretations of history and the underlying visions of the national community and the state. Therefore, the stakes are high, and the significance of cultural expertise provided by historians is considerable.

\section{Method}

Three existing databases of Polish case law were searched for court decisions in which issues of broadly understood culture featured prominently, and where references to expertise were present. ${ }^{7}$ A sample of 400 court decisions was collected based on repeated searches including keywords such as the names of various disciplines in the social sciences (anthropology, cultural studies, sociology, media studies), as well as keywords related to culture(s) - ranging from those related to "distant" cultures (such as hijab or kafala) to those related to the dominant Polish culture (such as those connected to the Catholic religion). Although the initial focus of this research was cases involving cultural diversity, only one instance of cultural expertise per se - related to an "honor killing", and involving the instruction of an expert Turkologist - was identified. It quickly became clear that any similar cases were vastly outnumbered by those in which expert knowledge was instrumental, but referred to aspects of the dominant Polish culture itself. ${ }^{9}$

7. First, it was the database of all the so-called common courts; that is, district, regional, and appellate courts, containing approximately 280,000 decisions; second, the database of administrative courts (ca. 153,000 records); and third, the database of the Supreme Court (ca. 55,000 records) (as of January 2019).

8. See Roger Ballard, “'Honour Killing'? Or Just Plain Homicide?” in Cultural Expertise and Litigation: Patterns, Conflicts, Narratives, ed. Livia Holden (New York: Routledge, 2011), 123-48.

9. Although the Polish society is becoming increasingly polarized as is the case in most other Western countries, it could be argued that we could speak of a single dominant Polish culture to a greater degree than we could speak of a single dominant culture in most other democracies in Europe. By Western standards, Poland remains an unusually homogenous country - in terms of language ( $98.2 \%$ Polish), ethnicity (ca. 96.9\% Polish), religion 
Among these cases, particularly numerous were cases connected to the use of historical expert knowledge, especially involving de-communization of the public sphere. Subsequently, I discuss the use of expert witnessing by historians - and the use of expert historical knowledge in court more broadly - based on a subset of the initial sample; that is, more than 100 decisions. They represent five types of cases, all of them heard by administrative courts. First, there were the so-called lustration (or "vetting") casesthat is, cases involving alleged collaboration with communist secret services, and the related sanction involving inability to perform certain jobs or run for public offices. Second, there were cases resulting from a recent law ordering local governments to change the names of places named after prominent Communist Party activists or events celebrating communist rule in Poland, and third, there was a relatively small number of cases involving the removal of communist era monuments. Fourth, there were numerous cases involving withdrawal of veteran status from soldiers of the communist security services or other military units. In all of these cases, expert opinions provided by historians employed at the Institute of National Remembrance had been crucial, although not always decisive. Finally, also included were cases appealing administrative decisions to refuse the award of benefits akin to citizenship to descendants of Poles exiled to Siberia. Although no experts informed court decisions in these latter cases, I look at them in more depth to identify the challenges faced by judges who had to make important cultural determinations based on their own understanding.

\section{De-communization: Collaboration with Communist Secret Services}

Under communist rule, as in other countries dominated by the Soviet Union, Poland was a police state. ${ }^{10}$ In August 1989, there were approximately 124,000 officers in various units, including 24,300 officers of the

\footnotetext{
(ca. $85.9 \%$ Catholic), and - in many ways - also culture. There are very few regional differences, and only pockets of strong regional identities exist. For a comprehensive discussion of the dominant Polish culture in relation to minority cultures of various kinds, see Janusz Mucha, "Dominant Culture As a Foreign Culture: Dominant Groups in the Eyes of Cultural Minorities," in Dominant Culture as a Foreign Culture: Dominant Groups in the Eyes of Minorities, ed. Janusz Mucha (New York: Columbia University Press, 1999), 7-23; as well as Janusz Mucha, "Cultural Minorities and the Dominant Group in Poland," Polish Sociological Review 114 (1996): 127-35.

10. See Maria Łoś and Andrzej Zybertowicz, Privatizing the Police-State (London: Palgrave Macmillan UK, 2000).
} 
secret police who supervised approximately 90,000 secret collaborators. ${ }^{11}$ The negotiated, rather than revolutionary, character of the Polish transition to democracy meant that the old Communist Party establishment was able to smoothly embrace the new system. With Soviet troops still present on Polish soil (until 1993), the democratic politicians were cautious to avoid violent turmoil, which had affected other post-socialist countries, such as Romania. Therefore, the politics of a "thick line," delimiting the difficult past from the brighter future, was implemented. Social peace came at a cost, however. Archives of the secret services were partly destroyed or, worse still, privatized and used for blackmailing and corrupting public figures. Many former communist leaders, including those responsible for outright crimes, such as the massacre of miners in December 1981, thrived, establishing themselves in key sectors, such as banking and media. As a result, public opinion in Poland became deeply divided over the evaluation of the Communist past. Some think that, in this period, Poland was a Soviet condominium, ruled by a foreign and alienated elite sent from the Kremlin; for others, it was a sovereign country of spectacular advancement of the working classes, and - last but not least - the country of their youth.

After a failed attempt in 1992, a law on lustration was finally adopted in 1997, requiring candidates for public offices and other positions to declare whether, from 1944 to 1990 , they had in any way collaborated with communist secret services. Those who had declared such collaboration were not disqualified from running for public offices or performing jobs requiring "impeccability of character," but it was assumed that public awareness of this fact would have limited their chances in any election. Providing a false statement, however, when confirmed legitimately by a court, resulted in disqualification, turning one into what has been popularly termed a "lustration liar" (kłamca lustracyjny); disqualification ensued also after failing to provide any statement. ${ }^{12}$ Among the affected professions were judges, prosecutors, attorneys, and candidates to the Parliament and most of the leadership positions in the central public administration. A special lustration court was established as a separate department of the appellate court in Warsaw in order to review the accuracy of these declarations. In 2006, a new law on lustration was adopted, providing legal definitions of what constituted collaboration with secret services and clarifying the

11. Paweł Piotrowski, "Przemiany w MSW w Latach 1989-1990," Biuletyn IPN 4:39 (2004): 54.

12. The law stipulates that issuing a false declaration may be sanctioned by the inability to run in the parliamentary elections (both for the lower chamber, the Sejm, and the upper chamber, the Senate), in the European parliamentary elections and the local government elections, for a period of between 3 and 10 years. 
range of people subject to the procedure ${ }^{13}$ Some provisions of this law were questioned by the Constitutional Tribunal in 2007. As a result, the number of people subject to the procedure was limited. ${ }^{14}$

From 2008 to 2015, the institute reviewed approximately 48,800 lustration declarations (with 300,000 still awaiting such a review). In 803 cases, courts issued final decisions; 459 people were found to have been secret collaborators, whereas for another 162 people, courts found no conclusive proof of such collaboration. ${ }^{15}$ Proponents of lustration interpret these data as indicative of the courts' excessive leniency, claiming that IPN prosecutors only presented courts with these cases when they had very strong evidence of collaboration. ${ }^{16}$

Analysis of lustration cases collected for this article confirms that courts often prefer erring on the side of defendants. Already in 2007, the Constitutional Tribunal ruled that "collaboration" was to be understood narrowly, as more than just a "declaration of intent," but encompassing actual activity, consciously undertaken, and involving providing information (decision no. Ko 2/07). In some cases, defendants argued for an even more restrictive interpretation; that is, requiring the IPN to prove that the information they provided went beyond information already publicly available, or - even more radically - that the information provided caused some tangible harm to the "independent Poland." Others argued that they could not be treated as collaborators because they had never received money for their "services." Although these interpretations were rejected by courts, judges applied rigorous standards to historical records documenting collaboration presented by the Institute.

For example, in the case of a former opposition member, who was described in one of the IPN's publications as a secret collaborator, the

13. See Natalia Letki, "Lustration and Democratisation in East-Central Europe," EuropeAsia Studies 54 (2002): 529-52, for a comprehensive discussion of various lustration experiences in Poland and five other East European countries.

14. For a detailed discussion of the lustration procedure in Poland and its evolution over time see Michał Krotoszyński, "Polish Lustration and the Models of Transitional Justice," Adam Mickiewicz University Law Review 1 (2014): 199-211.

15. Andrzej Grajewski, "Psucie Lustracji," Gość Niedzielny, 23.04.2015, https://www. gosc.pl/doc/2443427.Psucie-lustracji (accessed July 10, 2019).

16. Even in those cases, in which perpetrators were ultimately found guilty of crimes, courts took an unusually long time to reach these verdicts. For example, in 2009, the Polish Supreme Court confirmed the guilty verdict for the militia functionaries who shot nine miners and wounded twenty-one at the "Wujek" mine; see Andrzej Paczkowski, "Twenty-Five Years "After"-The Ambivalence of Settling Accounts with Communism: The Polish Case," in Remembrance, History, and Justice: Coming to Terms with Traumatic Pasts in Democratic Societies, ed. V. Tismaneanu and B. C. Iacob (Budapest: Central European University Press, 2014), 239-56. 
court rejected the evidence because some of the documents lacked the official stamp and signature of the defendant. ${ }^{17}$ In the case of the former president of Gdańsk University, accused of collaboration by the press, the court ruled that surviving archival records were incomplete (some important types of documents were missing) and, therefore, insufficient to prove collaboration. The newspaper was ordered to publish an apology, but the claim for damages was dismissed. ${ }^{18}$ Therefore, the court ruled that the professor was not guilty of collaboration, although a signed declaration of collaboration and reports of conversations survived and despite the fact that the journalists consulted prominent historians, Sławomir Cenckiewicz and Piotr Gontarczyk, leading experts on secret files of the communist intelligence services, who confirmed that the documents indeed indicated collaboration.

An even more prominent case of lustration is the ongoing series of court cases involving allegations that Lech Wałęsa, emblematic leader of Solidarity movement throughout the 1980s, winner of the Nobel Peace Prize in 1983, and the first non-communist president of the country from 1990 to 1995 , had been a secret collaborator of the security service from 1970 to 1976. Although his collaboration has been thoroughly documented-most comprehensively in a book by Cenckiewicz and Gontarczyk $^{19}$-Wałęsa has vehemently denied these allegations. Although he has indicated that he did indeed in some way collaborate (or rather, "had signed something"), the ex-president has repeatedly sued people, including former colleagues from the opposition, for defamation. In several of these court cases, such as those against Krzysztof Wyszkowski in 2014 and Henryk Jagielski in 2017, courts have called on historian Sławomir Cenckiewicz to provide expertise. Interestingly, Cenckiewicz was not instructed as an expert witness but was, instead, heard as a regular witness. In fact, what he did was to provide an expert witness statement, presenting both known and newly found archival documents indicating the fact of Wałęsa's collaboration. After repeated threats to sue, Wałęsa did file a suit against the historian and several other people, including a prominent sociology professor and an advisor to Polish President Andrzej Duda, Andrzej Zybertowicz, in February 2019. ${ }^{20}$

17. Appellate Court in Łódź, I ACa 433/13.

18. Appellate Court in Warsaw, VI A Ca 1813/14.

19. Sławomir Cenckiewicz and Piotr Gontarczyk, SB a Lech Wałęsa. Przyczynek Do Biografii (Gdańsk: Instytut Pamięci Narodowej, 2008).

20. Jacek Gądek, "Wiemy, Kogo Lech Wałęsa Chce Pozwać. Na Liście Jest Kilkanaście Nazwisk," Gazeta Wyborcza, 2019, http://wiadomosci.gazeta.pl/wiadomosci/7,114884,2445 5223, wiemy-kogo-lech-walesa-chce-pozwac-na-liscie-jest-kilkanascie.amp (accessed July 10, 2019). 
Zybertowicz had been sued earlier by several other people after he discussed their collaboration with the secret services.

In other similar, albeit less prominent cases, judges often set the expectations high for journalists covering issues of collaboration. Especially in cases involving former opposition members who - in light of the archival records - had also probably been collaborators of secret services, courts usually found that the presented evidence was not conclusive and ordered journalists and historians to publish apologies. At the same time, judges were reluctant to accept claims of damages, possibly for fear of a chilling effect on public and scholarly discussion of the country's past.

Despite these reservations, in essence, the courts accepted the expertise presented by historians and prosecutors working at the Institute as authoritative. Importantly, IPN's prosecutors were careful to limit their claims to factual statements on the contents of the archives, not to their interpretation as evidence of collaboration. External expertise was rarely sought and was not readily available. The only real alternative to IPN historians would be ex-officers of the Communist Party secret police. Relying on their "expertise" to judge the moral standing of former opposition members would obviously be difficult to accept. Still, at least two cases courts relied on special information provided by regular witnesses (of unspecified professional background), acting as de facto court witnesses in "operational methodology and techniques" of the Communist Party secret services. ${ }^{21}$ In both cases, courts rejected defendants' appeals pointing to the procedural flaw in such a move (i.e., reaching conclusions contrary to the witnesses' testimony). In several other cases included in this analysis, courts explicitly rejected parties' motions to appoint expert witnesses, finding the expertise provided by the IPN to be sufficient.

\section{De-communization: Changing Street Names}

In 2016, 27 years after the fall of the communist regime, a law "prohibiting propagation of communism or a different totalitarian regime through the names of buildings and public facilities" was passed.22 Although the most blatant symbols of Stalinism had been eliminated immediately after

21. For a methodological discussion of the challenges in researching and interpreting Communist Party secret police files in Poland, see Krzysztof Brzechczyn, "The Reliability of 'Files' and Collaboration with the Security Service (SB) in Poland: An Attempt at a Methodological Analysis," Hungarian Historical Review 3 (2014): 257-84.

22. This law (Ustawa $z$ dnia 1 kwietnia 2016 r. o zakazie propagowania komunizmu lub innego ustroju totalitarnego przez nazwy budowli, obiektów i urzadzeń użyteczności publicz$n e j$ ), dated April 1, 2016, enforced the prohibition of the propagation of communism or other 
the political change in 1989, hundreds of streets and squares remained, largely named after people less clearly perceived as representatives of the "ancien régime." Some of these patrons - apart from being prominent communist activists - had also been important figures in local communities, writers, or scientists. Over decades, inhabitants became used to these names, and changing them involved both practical problems (such as obtaining new identity documents or driving licenses with the new address), as well as financial costs to the local government (such as new street signage and replacing official seals). To address these concerns, the government offered a refund of any associated costs to those local administrations that promptly renamed the problematic streets. Additionally, inhabitants of the affected streets were allowed to retain documents with old addresses, and many local governments waived any fees associated with issuing new documents.

The new law, amended in 2017 to include monuments, required local administrations to obtain opinions from the IPN confirming that a particular street name was indeed subject to change. The Institute also invited local governors to seek information when facing doubts as to whether the particular patron indeed symbolized the communist regime. A list of 107 street names subject to change was published on the Institute's Web site, along with biographical or historical notes emphasizing the problematic activity of the patron. In the case of these names, links with the communist regime were clear and names of the old patrons were replaced. Most of the changes were voted in by local governments in compliance with the new law. Where local authorities did not do it, governors, representing central authorities, issued relevant decisions, often provoking controversies and leading to lawsuits.

In 2017 and 2018, administrative courts invalidated a vast majority of the incriminated administrative orders to change the names of streets. In some cases, judges explicitly shared the opinion of local governments, appealing the decision on the grounds that the patron "was not that bad," citing, for example, that the person was also a scholar or a local activist. Usually, however, judges emphasized the procedural flaws of the "opinion" provided by historians working at the IPN. Instead of an opinion, judges reasoned, the IPN provided a list of names subject to change, giving no proper reasons, such as biographical details of the old patron that indicated his or her problematic activity. In one such case, the judge noted: "The ordinance contains information resembling a copy of a bio taken from encyclopaedic sources, often incomplete, devoid of any features of

totalitarian regimes by names of buildings, facilities, and public utilities (amended twice - in June 2017 and December 2017, to include monuments). 
analysis." This argument is surprising, given the fact that IPN's Web site lists many of the most popular street names subject to change, and each patron's biography is discussed at length, emphasizing the problematic activity. ${ }^{23}$ Although this information was not formatted to suit the legal discourse - for example, it did not contain any arguments as to why a person who had been a secretary of the Communist Party should be seen to be a symbol of communism - the link was fairly obvious.

In other cases, courts annulled administrative decisions to change street names commemorating the "liberation" of a given town by the Red Army in late 1944 or early 1945 . These "liberation days" were heavily celebrated during communist rule, but while putting an end to German occupation, they also marked the beginning of communist rule over a particular territory. Because only the day and the month were included in the street name, many local governments tried to argue that the date did not represent the entrance of Soviet troops, but rather a different historical event (that had happened years earlier or later), falling on the same day and month. In this way, the hassle of changing the name could be avoided, while a new event could be substituted for the "liberation." Similarly, in several instances, courts accepted the local government's decision to only slightly modify the name of a street, when the name commemorated a military unit wherein many Polish citizens had been compelled to serve, as an honor to the soldiers, not to the unit itself. Courts invariably accepted this tortuous argumentation and overturned relevant administrative decisions prohibiting such "creative" interpretations of patrons or events. However, the IPN had not advocated a universal replacement of these names, but rather encouraged local debates over their meaning and replacement in those situations, when a date was indeed found to be perceived by the local inhabitants as marking the beginning of the Soviet rule. ${ }^{24}$ This attests to the relative de facto discretion that local governments had when implementing the law, especially when it came to the (re)interpretation of the meaning of historical events (such as "liberation"), as well as ties of historical figures to the communist regime.

Another contested aspect of the change regarded the new street patrons. Because the new names were indicated by the voivode - governor, a local representative of the central government - these figures disproportionately

23. See the list of street names subject to change published on the Institute's Web site: https://ipn.gov.pl/pl/upamietnianie/dekomunizacja/zmiany-nazw-ulic/nazwy-ulic/nazwydo-zmiany (accessed July 10, 2019).

24. Oświadczenie w sprawie zmian nazw ulic wskazywanych jako podlegajace zmianie na terenie gminy miejskiej Kołobrzeg, 14.11.2017, https://ipn.gov.pl/pl/dla-mediow/komunikaty/ 42794,Oswiadczenie-w-sprawie-zmian-nazw-ulic-wskazywanych-jako-podlegajace-zmianiena-.html (accessed July 10, 2019). 
represented values close to the right side of the political spectrum. Often, the new patron suggested was the late President Lech Kaczyński, killed in a plane crash in Smolensk, Russia, where he was about to take part in the commemoration of the 70th anniversary of the massacre of almost 22,000 Polish citizens (including over 10,000 officers) by the Soviets in March 1940. With his twin brother, Jarosław, now the de facto key figure in Polish politics, to some, Lech came to symbolize new divisions, rather than unity for the grieving nation. The reasons for the catastrophe still provoke fierce debate and conflicting opinions. However, many other streets were offered new patrons from among the ninety-six prominent representatives of the Polish state who were also killed in the crash. ${ }^{25}$

\section{De-communization: Removing Monuments}

Separately, under the revised law on de-communization, the IPN listed 469 monuments subject to removal. They included, among others, objects glorifying the Red Army, the so-called Polish-Soviet brotherhood-in-arms, and Soviet guerrilla fighters. The Institute decided that the removed objects would not be destroyed but rather transferred to a newly established Cold War Museum in Podborsk, an old Soviet depot for nuclear warheads. ${ }^{26}$ The idea was to avoid turning the exposition into a sort of amusement park by locating the old symbols of communist domination next to a military facility where the rockets meant to annihilate the West (Poland included), in case of the Cold War turning hot, had been stored. Additionally, the place was a top-secret facility, with only about a dozen Polish citizens aware of its true purpose; turning it into a museum was intended to powerfully illustrate the real, life-changing significance of the democratic transition, with its peaceful character and transparency.

As of yet, very few cases regarding the de-communization of monuments have reached the courts. The most significant case involved the monument commemorating the so-called "Polish-Soviet brotherhood-in-arms" in Warsaw, which had been painted red by two young men in 2011, and was broadly nicknamed as "Four Sleeping Brothers." Shortly before, the monument had been scheduled for relocation, because of the construction of a new metro station. After the incident, the monument was sent for

25. Wiktor Ferfecki, "Dekomunizacja: Nowi patroni ulic wygodni dla PiS," Rzeczpospolita, January 16, 2019.

26. See: IPN przygotuje ekspozycję w Muzeum Zimnej Wojny w Podborsku, June 29, 2017, http://ipn.gov.pl/pl/aktualnosci/40787,IPN-przygotuje-ekspozycje-w-Muzeum-Zimnej-Wojnyw-Podborsku-Warszawa-29-czerwca-.html (accessed July 10, 2019). 
conservation, but the IPN mobilized public opinion against returning it to the original prestigious location, and ultimately the monument was donated to the Museum of Polish History. Interestingly, polls conducted in 2012 and 2013 showed that the majority of Warsaw's inhabitants wanted the monument to return. ${ }^{27}$ The court dismissed the case, providing an unusually long explanation that included numerous references to historical sources and expertise. Judges decided to include several books in court files, and they concluded that the monument in question was "merely a symbol of communism, historical deceit, and a symbol of forced occupation." 28

A more recent case regarded the monument in Rząbiec near Kielce. The object, erected in 1952, glorified the battle between the Polish People's Army assisted by Soviet diversion groups and the Polish anti-communist National Armed Forces, possibly assisted by the Germans, in September 1944. It commemorated the sixty-seven Soviet troops executed after the battle, who died allegedly "fighting for national and social liberation of the Polish people." The case against three young men who defaced the monument with red paint was dismissed by the regional court in Włoszczowa in March 2018. The court noted that the construction was not damaged, and that the monument had already been listed for removal. This verdict was upheld in October 2018 by the district court in Kielce, after a veteran association in charge of the monument appealed the decision. Ordo Iuris, a conservative think tank, provided legal aid to the defendants and arranged support from three prominent historians, presenting opinions highlighting the historical context of the monument. The IPN presented an opinion confirming that the monument was to be removed. Somewhat unexpectedly, the monument was dismantled soon after the first verdict by the veteran association itself. ${ }^{29}$

27. See Barometr Warszawski, http://www.um.warszawa.pl/sites/default/files/attach/ o-warszawie/BW_XI_12.pdf (accessed July 10, 2019).

28. District court Warsaw-South, III K 794/11, August 19, 2015. See also: Znieważenie „Czterech Śpiących” $i$,Wdzięczności Armii Radzieckiej” prawomocnie umorzone, October 30, 2015, https://wpolityce.pl/polityka/270243-tylko-u-nas-zniewazenie-czterechspiacych-i-wdziecznosci-armii-radzieckiej-prawomocnie-umorzone (accessed July 10, 2019).

29. For a critical discussion of the de-communization efforts after 2015, see Tomasz Stryjek, "The Hypertrophy of Polish Remembrance Policy after 2015: Trends and Outcomes," Zoon Politikon (2019): 43-66. Stryjek argues that the intensification of efforts in the wake of the 2015 parliamentary victory of law and justice has led to a "hypertrophy" of remembrance policy, and resulted in excessive focus on martyrologic and heroic experiences. 


\section{Veteran Status}

During the war, the Polish resistance movement was one of the best organized among the German-occupied European countries. In 1944, the Home Army alone - the biggest of the existing organizations - numbered approximately 400,000 sworn members. Since the Soviet invasion of eastern Poland on September 17, 1939, the Soviet Union was perceived to be as much of an enemy as the Germans. The communist regime was installed in postwar Poland, despite active resistance by vast sections of Polish society, primarily as a result of the presence of the Red Army on Polish soil. Armed resistance against communist rule was especially fierce in 1944 45 , but continued until the late 1940 s, particularly in the mountainous regions of southern and southeastern Poland.

Members of the underground were vilified in the official propaganda as fascists or armed criminal bands. For decades under communism, one's record of having been a member of the Home Army, at best, resulted in discrimination in education and employment opportunities and, at worst, meant prison or even a death sentence. On the other hand, those engaged in fighting the underground were awarded veteran status and the associated benefits for their "armed struggle to strengthen the rule of the people."

Somewhat ironically, after 1989, these attempts to erase any memory of those fighting for independent Poland contributed to their new status as national heroes, the "cursed soldiers" (żotnierze wykleci), as they came to be called. This cultural shift in the memory of war and postwar events was reflected in a series of laws that provided for withdrawal of veteran status from people who had fought against the Polish independence underground in the 1940s, or for decreasing the amount of their retirement benefits. The first attempts, in the early 1990s, proved ineffective, as the new law was vetoed by the president on the grounds that it assumed collective responsibility. ${ }^{30}$ A subsequent amendment in 1997 and new provisions adopted in 2009 helped bolster the process. Already in 1991, the new Office for Veterans and Repressed Persons was created. A definition of the "security apparatus" was now offered, and an exception was created for those officers of the security forces who could prove that they had not been involved in fighting against the underground.

Since 2000, administrative courts have issued more than 2,100 decisions in cases involving complaints of those who had lost their veteran status and benefits. Claimants usually argued that their squads were not involved in

30. Renata Soszyńska and Rafał Leśkiewicz, "Odbieranie przywilejów funkcjonariuszom komunistycznej bezpieki w wolnej Polsce (aspekty historyczno-prawne)," Aparat Represji w Polsce Ludowej 1944-1989 1 (2011): 79. 
fighting the independence underground, but rather were fighting "criminal bands," the Ukrainian nationalists ("Ukrainian Insurgent Army") or the alleged Nazi stay-behind operation "Werwolf," in which German guerrilla forces would stay behind enemy lines. Others argued that they were not involved in combat, but had been delegated to administrative tasks. Courts typically cited historical sources (those published after 1989) to establish the exact nature and timing of the operations by particular armed units in specific regions of the country. They also relied on archival documents of the communist Veteran Service (Urzad ds. Kombatantów), through which prospective veterans were encouraged to emphasize the serious risks that they had run over the course of their service as a result of "armed struggle," and through which, in their applications or vitae, they claimed to have fought the "reactionary underground." Many claimants had indeed been awarded special medals for their service to the communist regime. Also, historical expertise was cited to dispel the largely mythical threat from Werwolf, and to establish the criminal nature of entire military units, such as the Internal Security Corps (Korpus Bezpieczeństwa Wewnętrznego [KBW]), established in 1944 specifically to fight the underground. In such cases, courts evoked the 2007 ruling by the Supreme Administrative Court, affirming that the mere fact of service in certain security services obliged the Veteran Office to withdraw the person's veteran status. ${ }^{31}$ As a consequence, the vast majority of complaints were rejected.

Claimants were successful, however, when courts found that they had served in the regular People's Army (which only delegated some troops to fight the insurgents), not in designated security units, or when the archival records of their service were insufficient or contradictory. For example, the Voivodship Administrative Court in Szczecin in 2005 annulled one decision and withdrew veteran status from a man whom the IPN had found to have been a member of a Soviet paramilitary unit, which was found by the Veteran Office to have been responsible for the extermination of several armed underground groups. ${ }^{32}$ The Veteran Office cited historical literature to substantiate its decision. The claimant also cited several historical sources, including a Polish translation of memoirs published in 1947 in the now-former Soviet Union, which presented a wholly different picture of the situation: he claimed that his unit had actually assisted Polish partisans, and that the KGB had arrested him on charges of collaboration with these "armed reactionary bands." The court focused on the fact that the particular unit in which the claimant had fought was not listed in the literature

31. Supreme Administrative Court, decision no. II OSK 255/06.

32. Voivodship Administrative Court in Szczecin, decision no. II SA/Sz 1337/04. 
cited by the Veteran Office. A careful analysis of the quoted sources resulted in a nuanced picture of multilayered political and armed conflicts among various armed groups in the specific period and region. In the court's opinion, these sources did not unequivocally prove that the claimant must have been involved in such activity. ${ }^{33}$

\section{Repatriation}

Cultural determinations proved also to be instrumental in decisions by administrative courts regarding the repatriation of people of Polish origin living in the countries of the former Soviet Union. Although these cases did not require (or foresee) any role for an expert (the IPN had no role in the procedures), quite unexpectedly, courts were tasked with defining "Polishness" based on judges' own understanding.

It is estimated that between $18,000,000$ and $20,000,000$ Poles or people of Polish origin live outside the home country, including approximately $2,500,000$ in the countries of the former Soviet Union. Many of them had been forced to stay in what became the Soviet Union after 1945, and did not have a chance to move to Poland. In 2007, a new law was enforced to facilitate the repatriation of those people; it was expected that up to $1,000,000$ would apply (instead, from 2008 to 2013, only $113,000 \mathrm{did})$. Successful applicants are entitled to obtain the so-called Card of the Pole (Karta Polaka), which attests that the holder-who is

33. Since 2016, apart from awarding or denying veteran status to soldiers of the underground repressed after 1944 by the Soviet and communist troops, the administrative courts have heard approximately twelve cases resulting from a 2015 law on "anti-communist opposition activists and people repressed for political reasons" (Ustawa o dziataczach opozycji antykomunistycznej oraz osobach represjonowanych $z$ powodów politycznych, Dz. U.2015.693, as of May 20, 2015). The law introduced a new status of "anti-communist opposition activist" and "a person repressed for political reasons," defining these as "a person who during the period from January 1, 1956 to June 4, 1989, for a total of at least 12 months, conducted, within the framework of organized structures or in cooperation with them, activities punished by criminal liability, aimed at Poland's recovery of independence and sovereignty, or respect for political human rights in Poland." The bill contains even more detailed provisions, indicating, for example, that eligibility resulted, among other criteria, from being held in custody for a minimum of 48 hours without charges, or arrested multiple times for shorter periods adding up to at least 30 days. Status holders are eligible to receive various benefits, including financial compensation. Applicants are requested to document their opposition activities themselves, and their records are verified by the IPN's archivists. In cases of doubt or missing documents, the IPN's archive obtains an opinion from the Institute's Bureau of Historical Research. See https://opozycja.ipn.gov.pl/op/ ustawa/61,Ustawa.html (accessed July 10, 2019) for details of the procedure. In all of the cases, complaints against decisions denying the status have been dismissed. 
not a Polish citizen - belongs to the Polish nation and is entitled to various forms of assistance. Cards are issued through an administrative procedure by Polish consuls (if the applicant resides abroad) or voivodes (governors of 16 voivodships; i.e., provinces, appointed by the central government), if the applicant has residence in Poland. Decisions by consuls can be appealed to a special body called the Council for Poles in the East (Rada do Spraw Polaków na Wschodzie), and decisions by voivodes can be appealed first to the Office for Foreigners and, subsequently, to a court of appeals.

Applicants are required to "demonstrate their relationship with Poland through at least basic knowledge of the Polish language, which they deem as mother tongue, and history, as well as knowledge and cultivation of Polish traditions and customs." ${ }^{\text {4 }} 4$ Applicants are also required to file a written declaration of their identification with the Polish nation and demonstrate some Polish ancestry or their involvement in a Polish organization. The interview takes 15-20 minutes and becomes-as one plaintiff put it in his appeal- "an exam on Polishness." Early on, the Ministry of Foreign Affairs developed guidelines for consuls on assessing language skills, including several hundred sample questions (e.g., about the Polish flag, national foods, dates of important events). Many of these questions were subsequently widely circulated and discussed in online fora for prospective applicants, who could use them to better prepare for the conversation.

As was anticipated in a vigorous debate preceding the introduction of the new law, the consular services and - subsequently-administrative bodies and, finally, the courts have found themselves in the middle of a debate to define Polish culture, with no clear-cut legal definitions of key concepts such as "Polish nationality," "Polish origin," and "identification with the Polish nation." In a 2012 case heard by the Voivodeship Court of Appeals in Warsaw, the court denied the appeal, citing as one reason that "the plaintiff claimed to have used to attend services at the Orthodox church along with his parents, who are orthodox ...., while in the East it is the Catholic faith that symbolizes Polishness." ${ }^{35}$ Although true in principle, the court's finding neglected the fact that there was considerable religious diversity in the eastern borderlands of prewar Poland. In a different case before the same court in 2013, in which the applicant emphasized and demonstrated her Catholic faith (including celebration of Christmas and Easter and knowledge of Catholic traditions and customs),

34. Ewa Żołnierczyk, "Karta Polaka—próba niełatwej oceny," Wrocławsko-Lwowskie Zeszyty Prawnicze 7 (2016): 211.

35. Voivodeship Court of Appeals in Warsaw, decision no. IV SA/Wa 1291/12. 
the courts ordered the application to be re-examined. ${ }^{36}$ Although the court explicitly said that it did not matter that the applicant did not seem to be a practicing Catholic, past religious practices seemed to have been weighed in the decision. Also, the court emphasized that the interview was not supposed to be an examination of facts, and it dismissed examples of applicant's factual errors and emphasized significant past experiences such as a trip to Krakow - a city of great historic importance for the Polish people.

A total of 114 similar decisions by administrative courts from 2009 to 2018 have been identified. Although the number of cases has been increasing, Poland's priorities in immigration policy have also recently significantly shifted. The booming job market and one of the lowest unemployment rates in the European Union mean that the country, for the first time since 1989, is trying to develop a full-blown immigration policy because it is concerned about attracting enough workers. One could therefore expect the Card of the Pole to be awarded more generously in the future. At the same time, the influx of immigrants from ever more distant cultures will increase the demand for cultural expertise in other geographic areas.

In each of the contexts reviewed-lustration, changing street names, removal of monuments, withdrawal of veteran status, and repatriationthe Institute's historians were formally obliged to inform courts' decisions, but judges often challenged their views, or decided to ignore them on procedural grounds. Thus, provision of cultural expertise to the courts by historians significantly departed from general patterns of expertise in other areas, such as medicine, psychology, property, or car accidents. In many of these spheres, the ombudsman reported in 2018, judges tend to uncritically rely on court experts, to the point of entrusting them with deciding the case. ${ }^{37}$ This is despite the fact that the current system of court expertise has often been described as deeply deficient (for example, for lack of proper validation of expertise, as well as inadequate training) and in January 2019, the Ministry of Justice has announced its comprehensive reform. ${ }^{38}$ Clearly, matters of culture - including historical judgementsare being treated by the judges as matters in which "expertise" is to be taken with a grain of salt, and in which common-sense interpretations

36. Voivodeship Court of Appeals in Warsaw, decision no. IV SA/Wa 2810/12.

37. "Co z zapowiadanym projektem ustawy o biegłych sądowych? RPO pyta resort sprawiedliwości," May 21, 2018, https://www.rpo.gov.pl/pl/content/rpo-upomina-sie-ozapowiadany-projekt-ustawy-o-bieglych-sadowych (accessed July 10, 2019).

38. The reform is supposed to centralize the system under the supervision of a reorganized Institute of Forensic Research in Krakow, require candidates for experts to obtain a special certificate validating their knowledge and skills, and introduce upper age limits for experts. See Patryk Slowik, "Wielka reforma systemu biegłych sądowych. Koniec z niezależnością ekspertów?" Gazeta Prawna, January 29, 2019, A12. 
are often feasible, and perhaps sufficient. At the same time, however, even when cultural evidence ultimately was not accepted by the court, expert opinions played a symbolic role, to which I turn next.

\section{Cultural Expertise and Historical Politics}

Building on previous work by Hegel, Honneth famously identified "struggle for recognition" as the "moral grammar" of contemporary social conflicts. ${ }^{39}$ For individuals in atomized and rich Western democracies, public recognition becomes one of the most valued resources and a bedrock of their identities, in need of constant reaffirmation. For Honneth, courts are the key arena — besides the media — where the struggle for recognition is won or lost. It could be argued that increasing diversity, and officially declared tolerance, indeed, celebration of diversity, have further enhanced the significance of courts as a symbolic forum. Unlike in many other areas, court judges are often not "democratic"; that is, they do not reflect the opinion of a majority, but rather that of a single or a handful of representatives in positions of power. Also, by their very nature, court decisions are usually exclusive: one party wins, and the other loses. This authoritative nature of court judgments is tempting in modern democratic societies, where other opinion makers, such as the media, politicians, and the academics, are (at least theoretically) striving to achieve maximum inclusion. Thus, in a world of growing complexity, the courts' role in reducing complexity becomes ever more important.

This universal struggle for recognition assumes new intensity in transitional contexts. Symbolic victory over communism (and other repressive regimes) highlights the significance of the court as a forum for re-enacting societal norms and values, as well as for eradicating old norms and values. Court decisions affirming the new democratic narrative are necessary for a symbolic victory over dictatorship.

In reference to Honneth, Haldemann has proposed conceptualizing transitional justice as recognition: "the kind of justice that is involved in giving due recognition to the pain and humiliation experienced by victims of collective violence. ${ }^{" 40}$ Haldeman suggests that transitional justice can be conceptualized beyond the traditional opposition between retributive and restorative justice in order to emphasize another dimension of justice:

39. Axel Honneth, The Struggle for Recognition: The Moral Grammar of Social Conflicts (Cambridge: Polity Press, 1995).

40. Frank Haldemann, "Another Kind of Justice: Transitional Justice as Recognition," Cornell International Law Journal 41 (2008): 675-737. 
symbolic recognition of the pain and humiliation experienced by the victim. ${ }^{41}$ Thus, he proposes to shift attention toward the victims, whose trauma now enters center stage. One example of this approach is the "women's court" of Sarajevo: an informal initiative to give voice to female victims of rape ${ }^{42}$ What Clark describes is an out-of-court, nongovernment forum for seeking symbolic vindication and recognition. Recourse to this particular forum can be explained by limitations inherent in the criminal procedure, which traditionally focuses attention on the perpetrator. It also represents a grassroots effort to empower a particular group of victims who are underserved by the bureaucratic official justice system. Although this approach is understandable and justified, one could argue that the significance of recognition is not limited to individuals' lived experience. Indeed, in cases in which both perpetrators and victims have long been dead (as in the Polish case of communist street patrons), and in which for a long time truth could not have been officially affirmed (e.g., historical truth about the real significance of events such as the "liberation" by the Red Army) as a result of political circumstances, recognition may become an even more important dimension of transitional justice than retribution or restoration.

The Polish case seems to illustrate a strategy of using courts as a vehicle to invalidate some and to affirm other interpretations of history. Although numerous other avenues exist for achieving these goals, such as freedom of academic research and varied media channels, courts are seen as a particularly desirable platform for validating claims. Academic experts produce increasingly conflicting interpretations, and the media speak to increasingly disparate audiences; courts, however, authoritatively affirm certain narratives, and they invalidate others.

Underscoring this conclusion, the Institute's research branch will probably soon become involved in a new procedure to deal with the expected civil lawsuits resulting from the amended law on the Institute of National Remembrance, revised in January 2018, to penalize "anyone who publicly or against the facts ascribes responsibility or co-responsibility to the Polish nation or state for crimes committed by the Third Reich or other crimes against humanity, peace and war crimes-will be subject to a fine or imprisonment of up to three years" (Article 55a). These provisions were predominantly meant to counter the occasional references to "Polish death camps" occurring worldwide, including in articles published in the renowned

41. Ibid., at 678 .

42. Janine Natalya Clark, "Transitional Justice as Recognition: An Analysis of the Women's Court in Sarajevo," International Journal of Transitional Justice 10 (2016): $67-87$. 
international press, as well as voiced by prominent public figures (including United States President Barack Obama in 2012). The proponents of this legislation emphasized that the new law's scope was very limited, addressing only statements ascribing the responsibility for historically documented atrocities committed by the Nazis to the whole Polish nation or the Polish state, and therefore did not attempt to prosecute any claims about crimes committed by individual Polish citizens or groups of Polish citizens. The law also explicitly exempted historical research and artistic expression. Despite these reservations, the new law provoked a substantial international outcry, with critics accusing the right-wing government of attempts to censor history and whitewash documented crimes committed by the Polish people during World War II against their Jewish neighbors. Shortly afterwards, another amendment, voted on June 27, 2018, removed art. 55a from the law. Although no lawsuits have yet reached the courts, the IPN's historians will likely provide expert opinions under the new law, putting them at the front line of contemporary debates over Polish national identity. $^{43}$

Thus, decisions by cultural experts often have immediate and serious practical consequences. This represents particular challenges for those social scholars, especially historians, who provide witness statements in these cases. Historian Dariusz Stola criticized the privileged position of the Institute for National Remembrance as a research center and highlighted lingering conflicts of interest that reduce its effectiveness and potentially undermine academic standards. He aptly nicknamed the Institute a "kind of special ministry for the difficult past." Undoubtedly, he said, it was also the "most important, visible and

43. In this context, it is worth mentioning several court cases involving Jan T. Gross, the author of a book devoted to the 1941 pogrom in Jedwabne, in which between 250 and 340 Jews were massacred by a group of Poles (and not the Nazi Germans, as previously believed). See Jan T. Gross, Neighbours. The Destruction of the Jewish Community in Jedwabne, Poland (Princeton, NJ: Princeton University Press, 2001). Although the investigation launched by the IPN partly confirmed Gross's account, it significantly reduced the estimates of the number of victims, and confirmed the complicity of Germans. The book sparked a heated debate in Poland, and resulted in a protracted court dispute involving one of the book's protagonists. In 2009, the Appellate Court in Warsaw found Gross not guilty of defamation, despite the fact that he had mistakenly attributed quotes to one of the men present in Jedwabne during the pogrom; see "Sąd: J.T.Gross nie musi przepraszać za książkę o Jedwabnem," Gazeta Prawna, July 23, 2009, A5. Although Gross did amend subsequent editions of his book to account for the wrong attribution, the courts also emphasized the fact that his book contained "historical truth," "served a publicly significant purpose," and was "admissible under the freedom of academic research."

44. Dariusz Stola, "Poland's Institute of National Remembrance: A Ministry of Memory?" in The Convolutions of Historical Politics, ed. Alexei I. Miller and Maria Lipman (Budapest: Central European University Press, 2012), 48. 
controversial institution of contemporary Poland," attracting public attention and shaping political discourse almost daily. Its telling name stands in contrast to the neutral-sounding name of its German counterpart (the Federal Commissioner for the Records of the State Security Service of the former German Democratic Republic, or Bundesbeauftragte für die Unterlagen des Staatssicherheitsdienstes der ehemaligen Deutschen Demokratischen Republik); also, the IPN encompasses a much broader scope, its tasks including prosecution of crimes. The IPN functions as an archive, research center, special division of the justice system (with a privileged position of its prosecutors), and, finally, an educational institution, disseminating results of its own research. ${ }^{45}$ No other academic institution in Poland can even remotely match the IPN's resources available for historical research. As a result, the Institute is able to attract talent from academia and set a research agenda in matters related to contemporary Polish history. Even though few question the integrity and academic standards of the IPN historians, Stola worries that the Institute's academic priorities may distort recent Polish historiography in subtle ways; for example, by focusing on the resistance against communism and downplaying the willing support or collaboration with the regime.

As has been discussed, these multiple roles and the resulting conflicts of interest have had consequences for the judges' perception of cultural expertise provided by the IPN historians. Although judges invariably recognize the Institute's experts as being reliable and competent to assist the courts, they also seem to be keenly aware of the political ramifications of the IPN's statutory role. Whenever possible, courts cited procedural grounds to reject or challenge expert opinions presented in support of the more questionable applications of the de-communization laws. This was especially clear in regard to street name changes. In such cases, courts were reluctant to become tools of the so-called "historical politics": attempts by state authorities to actively shape the historical discourse and popular memory of historical events. ${ }^{46}$ Yet, in other contexts (such as rehabilitation of victims of Stalinist oppression, or enforcing the lustration procedure where collaboration was evident and harmful), judges seemed to consciously approve the court's role in affirming new historical narratives.

45. Ibid., 54. For an alternative view on the Institute, see Antoni Dudek, Instytut. Osobista historia IPN (Warszawa: Czerwone i Czarne, 2011). Although Dudek, a history professor and long-time employee of the Institute, shares Stola's criticism and advocates a separation of the IPN's research and investigation functions, his overall assessment of the Institute's first decade of existence is largely positive.

46. Alexei I. Miller and Maria Lipman, eds., The Convolutions of Historical Politics (Budapest: Central European University Press, 2012). 
There is yet another aspect of cultural expertise provided by historians in Polish courts: the particular status of the intelligentsia and the prominent position of historians among Polish intellectuals. Intellectuals in Poland -as well as in several other post-communist countries - have come to enjoy a much wider social influence and the associated prestige (although not financial awards) than their Western counterparts. In a region where wars and foreign domination have repeatedly annihilated fortunes and destroyed property, intellectual capital came to be particularly valued because it was easier to transfer it between generations, compared with other more traditional forms of capital. ${ }^{47}$ In the first decade after the transformation, higher education was also an effective protection against the unemployment that massively affected representatives of all other social classes. Combined with the de facto systemic discrimination against other social groups, such as private entrepreneurs, and given the relative irrelevance of legal professions under the communist regime, all this contributed to the unusually high status of intellectuals.

After 1989, this status has ensured intellectuals' prominence in public roles as commentators, advisors, experts, and-first of all-politicians. In stark contrast to the situation in other Western democracies, Polish politicians have been disproportionately recruited from among academics (or, more broadly, educators), rather than from among lawyers or businesspeople. For example, among members of the German Parliament (Bundestag) elected in 2017, 115 of the 708 MPs were lawyers, compared with only 26 "teachers and university lecturers." Similarly, among the 541 members of 115th United States Congress, elected in 2016, 194 have previously had a career in public service or politics, 179 came from business, 168 were lawyers (held a law degree), and only 99 were educators (including not only teachers or university professors, but also school administrators). In Poland, among the 460 members of the Parliament elected in 2015, "teachers and university professors" (58) were second only to career parliamentarians (67) - many of whom, however, could also claim an academic background; lawyers came in third (47). Fifteen MPs specifically identified themselves as historians. This prevalence of people with an academic background is even clearer at the top positions in government. Bronisław Komorowski, Polish president from 2010 to 2015, was a historian by education, and one of his closest advisors was Tomasz Nałęcz, a history

47. Tomasz Zarycki, "Hipokryzja Na Peryferiach,” Nowe Peryferie, 2015, https://noweperyferie.pl/index.php/2015/01/hipokryzja-peryferiach-czesc (accessed July 10, 2019); and Tomasz Zarycki, Rafal Smoczynski, and Tomasz Warczok, "The Roots of Polish CultureCentered Politics: Toward a Non-Purely Cultural Model of Cultural Domination in Central and Eastern Europe," East European Politics and Societies: and Cultures 31 (2017): 360-81. 
professor from Warsaw University. Among fifteen prime ministers from 1989 to 2018, two were historians. The first was Donald Tusk, an influential prime minister from 2007 to 2014, and president of the Council of the European Union ever since. Although the current prime minister, Mateusz Morawiecki, made headlines for his decision to leave a top position in banking for the new job, his first degree was in history. Ironically, his predecessor, Beata Szydło (known for her government's restrictive immigration policy during the 2016 immigration "crisis") obtained her degree in ethnography. Three prime ministers had been fully tenured professors, a fact corresponding with the top position of university professors in rankings of occupational prestige in Poland. ${ }^{48}$

These academic credentials of Polish lawmakers and government members, combined with the relative weak representation of other professions (such as business), may be a significant factor in shaping courts' willingness to engage experts in matters of culture. For decades, Polish universities have been underfunded, forcing academics to combine teaching and research with other roles, such as entrepreneurs, experts, advisors, and politicians. Political actors often reach out to academia for support in hotly debated public issues. As a result, it is difficult to find academics able to provide unbiased, professional opinions who enjoy bipartisan credibility. Also, the self-identification of key political leaders as intellectuals may be leading them to consider themselves as experts in matters of culture, without the need for further expertise. Finally, key decision makers are people who have been actively involved in democratic opposition against the communist regime and have a good understanding of the events and processes of the recent past. Therefore, the particular prominence of academics and intellectuals in Polish public life may have had the inadvertent effect of decreasing demand for academic experts in their formal roles as cultural experts assisting the courts.

\section{Conclusion}

It is notable that in the only areas where cultural expertise is routinely sought by Polish courts - namely refugee procedure and de-communization

48. Across various polls conducted in Poland, the tenured professor has ranked either no. 1 or no. 2, just behind the firefighter; see Henryk Irina Tomescu-Dubrow, Słomczyński, Kazimierz M. Domański, Zbigniew Dubrow, Joshua Kjerulf Sawiński, and Dariusz Przybysz, Dynamics of Class and Stratification in Poland (Budapest-New York: Central European University Press, 2018), 176. Although academic scholars tend to rank at or near the top also in many other countries, in the classical National Opinion Research Center poll conducted in the United States in 1989, "professor" ranked eleventh. In more recent polls conducted in the United States, "scientist" usually ranked very high, but natural scientists are not typically perceived as intellectuals in Polish public discourse. 
procedures - provision of expertise has been thoroughly institutionalized. With regard to immigration, institutionalization of expertise allows the state to maintain its restrictive immigration policy, with the aim of reducing diversity in the hope of escaping the perceived challenges of Western multiculturalism. By institutionalizing expert witnessing in matters of history, authorities attempt to secure victory in the struggles over the dominant interpretation of the country's past. This latter struggle is particularly complicated because Polish society remains deeply divided on the issue of the status of the Polish People's Republic (1944-89).

This does not mean that experts working in these two areas merely uphold narrowly defined partisan goals. In both cases, courts seem to rely on their expertise precisely because of the experts' reputation for integrity and high professional standards. At the same time, there is no viable alternative to these institutionalized sources of expertise. In the immigration procedure, lawyers working for the nongovernmental organizations do occasionally present courts with alternative sources (based largely on available reports by renowned international charities, such as Amnesty International). In matters related to history, the parties have the option to challenge expert opinions provided by the IPN by seeking help from independent historians with different views on certain aspects of Poland's recent history. They may also appeal to judges' own understanding of historical facts. Still, in both cases, institutional expertise enjoys a privileged status, whereas private opinions are usually viewed as a mere reinstatement of the parties' positions. Judges often emphasize the lower status of private opinions in Polish procedural criminal, civil, and administrative law.

Regardless of this monopolization of cultural expertise by the state, the evolution of standards in expert witnessing is evident. Judges tend to appoint social scientists as experts more frequently; also, litigants themselves tend to seek help from cultural experts more often. When citing written sources, such as reports from various international organizations (in the immigration context) or expert opinions provided by the Institute of National Remembrance, judges now increasingly give full details of these sources (such as authors, titles and publisher), and look for multiple sources. This is a considerable improvement compared with just a few years ago, when judges typically only generically referred to "available reports" or "sources." 